
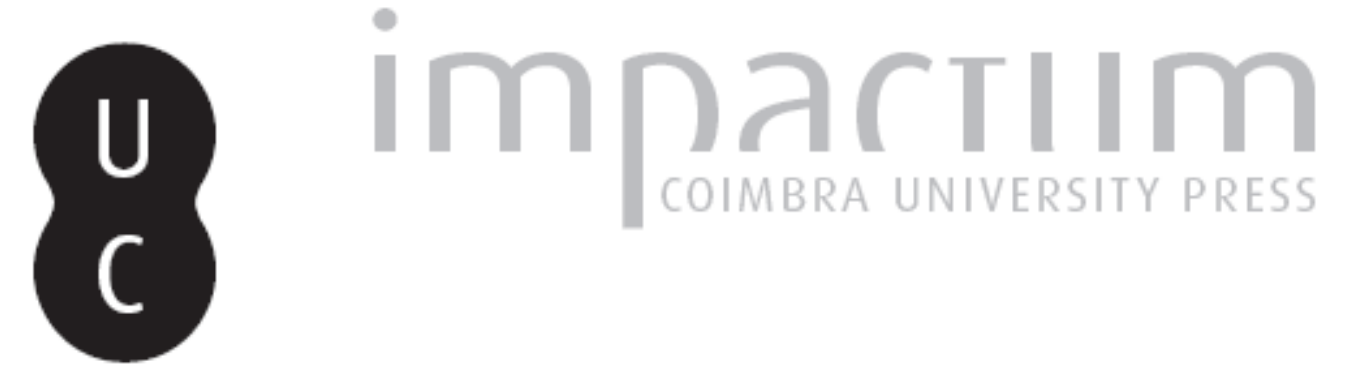

\title{
La relectura positiva de la tradición poética griega en el Banquete de Platón
}

Autor(es): $\quad$ Soares, Lucas

Publicado por: Imprensa da Universidade de Coimbra

URL persistente:

URI:http://hdl.handle.net/10316.2/43594

DOI:

DOI:https://doi.org/10.14195/2183-4105_17_2

Accessed : $\quad$ 26-Apr-2023 14:53:15

A navegação consulta e descarregamento dos títulos inseridos nas Bibliotecas Digitais UC Digitalis, UC Pombalina e UC Impactum, pressupõem a aceitação plena e sem reservas dos Termos e Condições de Uso destas Bibliotecas Digitais, disponíveis em https://digitalis.uc.pt/pt-pt/termos.

Conforme exposto nos referidos Termos e Condições de Uso, o descarregamento de títulos de acesso restrito requer uma licença válida de autorização devendo o utilizador aceder ao(s) documento(s) a partir de um endereço de IP da instituição detentora da supramencionada licença.

Ao utilizador é apenas permitido o descarregamento para uso pessoal, pelo que o emprego do(s) título(s) descarregado(s) para outro fim, designadamente comercial, carece de autorização do respetivo autor ou editor da obra.

Na medida em que todas as obras da UC Digitalis se encontram protegidas pelo Código do Direito de Autor e Direitos Conexos e demais legislação aplicável, toda a cópia, parcial ou total, deste documento, nos casos em que é legalmente admitida, deverá conter ou fazer-se acompanhar por este aviso.

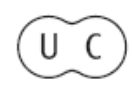


ISSN 2079-7567 eISSN 2183-4105

0

\section{Established 1989}

http://platosociety.org/

\section{Papers}

Cristina lonescu Elenchus, Recollection, and the Method of Hypothesis in the Meno

Lucas Soares

La relectura positiva de la tradición poética griega en el Banquete de Platón

Etienne Helmer Le commerce de la vérité: économie et commerce dans les Lois de Platon

Alan Pichanick

Socratic Silence in the Cleitophon

Thanassis Gkatzaras The Form of the Good in Plato's Timaeus

James M. Ambury Dialectical Epimeleia:

Platonic Care of the Soul and Philosophical Cognition
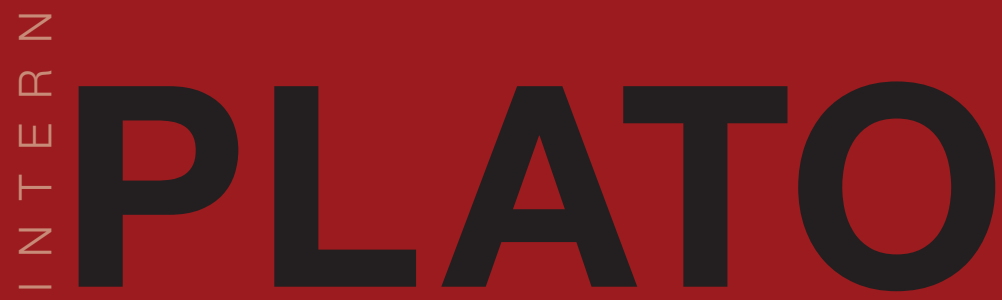

Book Reviews

Nicholas Zucchetti

Essays on Plato's Epistemology by Franco Trabattoni

Alan Pichanick

Socrates and Self-Knowledge by Christopher Moore
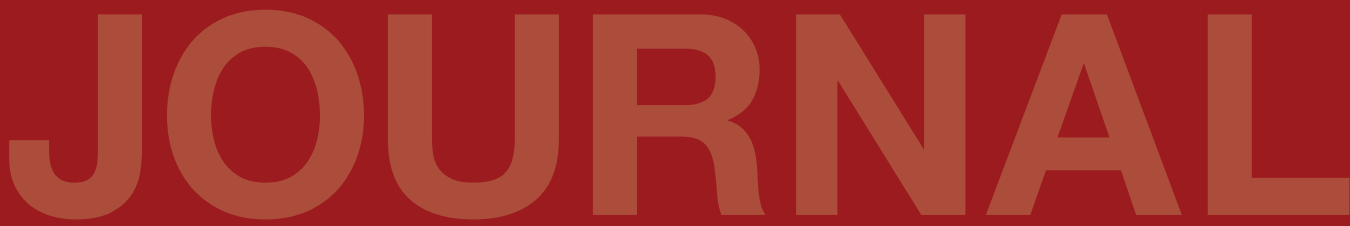

Société Platonicienne Internationale

Associazione Internazionale dei Platonisti

Sociedad Internacional de Platonistas

Internationale

Platon-Gesellschaft

Imprensa da

Universidade

de Coimbra

Coimbra

Universiy

Press 


\section{La relectura positiva de la tradición poética griega en el Banquete de Platón}

\author{
Lucas Soares
}

Universidad de Buenos Aires

lucso74@gmail.com

\section{ABSTRACT}

The Platonic reevaluation of traditional poetry in positive terms that we read in the Phaedrus, in as much as it is conceived therein as a valuable educational resource for posterity (Phaidr. 245a1-5), does not strictly imply anything new in the Platonic corpus, but rather a systemization and complementation of a set of ideas about the origin and function of poetry that Plato had already shared in some of his early, transitional and late dialogues. From this broad set of ideas, I am interested in this study in concentrating especially on a series of passages taken from the Symposium, in order to compile two lines of analysis in this paradigmatic late dialogue which, I understand, constitute a clear precedent for the positive conception that Plato finally assumes about traditional poetry in the Phaedrus. Keywords: Plato; Symposium; Poetry; Tradition; Rereading.

\section{INTRODUCCIÓN}

Así como a lo largo de sus diálogos Platón somete a un continuo reexamen su teoría de las Ideas, lo mismo cabe decir respecto de otros tópicos centrales que estructuran su filosofía, como por ejemplo la cuestión del éros, de la manía y, en lo que atañe a nuestro tema, la del estatus atribuido a la poesía tradicional. Para el caso del éros, piénsese en las diferencias estructurales que exhiben Banquete y Fedro, en tanto que en el primer diálogo se le niega al amor su condición de dios, mientras que en el segundo se le restituye su carácter divino; ${ }^{1} \mathrm{y}$, en lo que respecta al tópico de la manía, la concepción negativa que de ella se desprende en algunos diálogos de transición, medios y en los dos primeros discursos del Fedro -el de Lisias y el primero de Sócrates-, y su posterior rehabilitación desde una óptica divina en la palinodia socrática. ${ }^{2}$ Es justamente este nuevo planteamiento que Platón formula allí respecto del valor y función de la manía el que tendrá una implicancia fundamental en su reevaluación de la poesía tradicional en términos positivos; pues liberada ya de las exigencias de racionalidad y de austeridad prescritas en República, tal poesía es concebida en Fedro como un valioso recurso educativo para la posteridad (Phaidr. 245a1-5). ${ }^{3}$ En efecto, el que allí recibe todos los honores y fama inmortal por sus obras no es precisamente el poeta cuerdo y austero de República, sino más bien el poseído o maniático. Podemos, en este sentido, decir que a la altura del Fedro Platón es plenamente consciente de que la cuestión del éros y la de la poesía tradicional demandan más de un enfoque analítico; o, dicho de otra manera, que es difícil, teniendo en cuenta sus constantes revisiones de tales tópicos, extraer una concepción unívoca sobre ellos.

Pero esta concepción de la poesía que puede leerse en Fedro no implica en términos estrictos 
una novedad dentro del corpus platónico, sino más bien una sistematización y complementación de un conjunto de ideas acerca del origen y función de la poesía que Platón, como veremos, ya había diseminado en algunos de sus diálogos de juventud, transición y madurez. De ese amplio conjunto, en lo que sigue me interesa concentrarme sobre todo en una serie de pasajes tomados del Banquete, a fin de relevar en este diálogo paradigmático de madurez dos líneas de análisis que, a mi entender, constituyen un claro antecedente respecto de la concepción positiva que Platón termina por asumir en Fedro sobre la poesía tradicional. En primer lugar, la aparición de una línea vinculada al tópico de la inspiración divina como origen del discurso poético; en segundo lugar -y en estrecha relación con lo anterior- una línea de consideración elogiosa sobre las obras de los poetas tradicionales. Veamos entonces cómo juega en el Banquete esta concepción positiva de la poesía tradicional que confluye en el Fedro.

\section{LA VALORACIÓN POSITIVA DE LA POESÍA TRADICIONAL EN EL DISCURSO DE SÓCRATES- DIOTIMA}

Desde el inicio del Banquete Platón deja asentado el motivo principal que da origen a la propuesta de Fedro, basada en que cada uno de los oradores presentes pronuncie un encomio en honor del dios Éros. Tal motivo es la falta de una acabada atención y caracterización de este dios por parte de la tradición poética griega. Recordemos aquella propuesta, recogida por Erixímaco:

Fedro, en efecto, me está diciendo a cada paso, lleno de indignación: ‘ ¿No es irritante, Erixímaco, que en honor de algu- nos otros dioses haya himnos y peanes compuestos por los poetas y en cambio en honor del Éros, que es un dios de tan elevada importancia y categoría, ni uno solo, entre tantísimos poetas que han existido, haya compuesto jamás siquiera un encomio?' (Symp. 177a5-b1). ${ }^{4}$

Si se tiene en cuenta esta falta de interés hacia la figura de Éros, que Fedro, a través de Erixímaco, resalta en los poetas, y que actúa a la vez como desencadenante de su posterior alabanza, podemos leer la serie de discursos pronunciados por los oradores, a la manera de un diálogo con la tradición poética en los términos de una rectificación y complementación de ésta en lo que toca a la esencia y propiedades del dios Éros. De allí se explica, por lo demás, el constante gesto de apelación a dicha tradición que puede advertirse en cada uno de los discursos pronunciados, apelación cuyo fin es dar sustento o valor de ejemplaridad a sus respectivas tesis sobre la genealogía, naturaleza y efectos de Éros. Baste como ejemplo de ello las diversas referencias a Homero y Hesíodo que leemos en los discursos de Fedro -quien también alude, entre otros, a Esquilo y Eurípides-, Pausanias, Erixímaco, Aristófanes, Agatón y Alcibíades. ${ }^{5}$ Pero es sobre todo en el discurso de Sócrates-Diotima donde me interesa centrar mi análisis, a fin de reconocer en él la valoración positiva de las obras de los poetas tradicionales destacada en diálogos previos. Acerca de esta referencia continua en la obra de Platón al contexto poético tradicional, Nusbbaum señala apropiadamente que la escritura de Platón constituye una alusión continua al contexto poético,

tanto en su elección de imágenes como en los relatos que contiene y en su estilo literario, hasta el punto de que el significado 
de muchos de sus aspectos importantes se nos escaparía si no tuviésemos en cuenta dicho contexto. ${ }^{6}$

El encomio a Éros por parte de SócratesDiotima retoma la estructura formal apuntada en el discurso previo de Agatón. En efecto, Diotima, vía Sócrates, hace en principio referencia a la naturaleza y propiedades de Éros, para luego pasar a describir sus obras o efectos en los hombres. En este último punto referido a las funciones de Éros, puede leerse una definición general de los términos 'poesía' (poíesis) y 'poeta' (poietés), cuya finalidad es ilustrar la distinción entre un uso 'genérico' y 'específico' (i.e. de sus especies particulares) del término 'éros'. Por un lado, es 'producción' (poíesis) todo lo que es 'causa' (aitía) de que algo pase del no ser al ser; de forma tal que las diversas actividades comprometidas en el conjunto de todas las técnicas son, en sentido amplio, 'producciones' (poiéseis), y sus 'artesanos' (demiourgoí), 'productores' (poietaí). ${ }^{8}$ Por otro, en sentido específico, son 'poetas' (poietái), propiamente hablando, los que se circunscriben a una parte del conjunto total de la producción, relativa al ámbito musical (Symp. 205c5-c9). ${ }^{9}$ La 'imitación' (mímesis) constituye así un cierto tipo de 'producción de imágenes' (poíesis eidólon), y el 'poeta' (poietés), en tanto lleva a ser algo que antes no era, un productor cuyo resultado es un producto específico: el 'poema' (poiéma). Como al respecto afirma Heidegger, este pasaje constituye un claro testimonio de la posición preeminente que adquiere la técnica poética dentro de la totalidad del arte griego:

Si finalmente aludimos con 'arte' a lo producido por un producir, a lo allí puesto en tal producir y al producir mismo, entonces el griego habla de poiein y poíesis. El hecho de que la palabra poíesis se haya reservado de manera especial para nombrar la producción de algo en palabras, o sea, el hecho de que poíesis, como 'poesía', se haya convertido preferentemente en el nombre del arte de la palabra, el arte poético, es un testimonio de la posición preeminente que adquiere este arte dentro de la totalidad del arte griego. Por ello tampoco es casual que Platón, cuando lleva a la palabra la relación entre arte y verdad y plantea una decisión de la misma, trate en primer lugar y de manera dominante del arte poético y del poeta. ${ }^{10}$

A través de esta caracterización general de los términos 'poesía' y 'poeta' en ambos sentidos (amplio y específico), y su consiguiente analogía con el término 'éros', Platón procura, además de revelar la equivocidad propia que denota el término 'poíesis', destacar la relación entre tres nociones clave que organizan el discurso de Sócrates-Diotima: el éros (en tanto impulso erótico-daimónico), la poíesis (en sentido amplio y estricto) y la inmortalidad. En efecto, el éros es, en última instancia, amor de la inmortalidad (éros tês athanasías, Symp. 207a3-4), cuya plasmación se expresa puntualmente en la naturaleza mortal -animal y humana- bajo la mediación de la 'generación', 'procreación' o 'reproducción' (diferentes formas de volcar el término 'poíesis'), procreación que implica, según el cuerpo, la poíesis de hijos naturales, y, según el alma, de hijos espirituales, siempre bajo el estímulo de la belleza:

Así, pues, los que son fecundos según el cuerpo se dirigen en especial a las mujeres y ésta es la forma en que se manifiestan sus tendencias amorosas, porque, según creen, se procuran para sí mediante la procreación de hijos inmortalidad, 
memoria de sí mismos y felicidad para todo tiempo futuro (Symp. 208e1-5). ${ }^{11}$

Los hombres que conciben en las almas llegan así a dar a luz la sabiduría y las demás virtudes, de las que precisamente son 'progenitores todos los poetas' (poietaì pántes gennetores) y cuantos 'artesanos' (demiourgôn) se dice que son inventores (Symp. 209a3-5). La dimensión erótico-poiética que Platón descubre en la poesía redefine en este sentido al poeta tradicional ('todos los poetas') como un tipo de creador especial que busca, por medio de su obra, alcanzar la inmortalidad. Ésta, en tanto causa final de ese impulso erótico-poiético ${ }^{12}$ que mueve a los poetas $-\mathrm{y}$ a los célebres legisladores, como veremos más adelante-, se traduce concretamente en 'obras del alma' o 'hijos del espíritu’. En una palabra, en la generación o procreación de virtudes tales como la moderación y la justicia, ligadas al ordenamiento de las ciudades y de las comunidades.

Nótese aquí resignificada la concepción de los poetas como 'padres' o 'progenitores' (gennétores) del saber en términos prácticos, concepción que ya podía leerse en un diálogo temprano como el Lisis, y que contrasta claramente con la opinión negativa del poeta tradicional como 'fabricante de apariencias' postulada en República. Dicho pasaje del Lisis se inscribe en el marco de una de las aporías en las que recae el diálogo al buscar definir en qué consiste la amistad (philía) o el ser amigo en los términos de una relación de reciprocidad entre el amante y el amado: 'Cuando alguien ama a alguien, ¿quién es amigo (phílos) de quién, el amante del amado, o el amado del amante? ¿O no se diferencian en nada?' (Lys. 212a8-b2). ${ }^{13}$ Ante esta aporía, Sócrates le propone a Lisis un cambio de rumbo, que implica una apelación a la palabra de los poetas tradicionales:
Y creo que es más fecundo volver allí donde nos desviamos, y preguntemos a los poetas, pues éstos son para nosotros como padres y guías del saber (patéres tês sophías kaì hegemónes). Ellos, naturalmente, no se manifiestan desinteresados de los amigos cuando los tienen; pero dicen que es un dios el que los hace amigos, haciendo que coincidan entre sí. Si no me equivoco dicen cosas como: 'Siempre hay un dios que lleva al semejante junto al semejante' y les hace conocerse. ¿Es que nunca te has tropezado con estos versos? (Lys. 213e4-214b1). ${ }^{14}$

Se plantea aquí un nuevo rumbo que apunta a la búsqueda de un principio explicativo que pueda dar cuenta de la philía, tomando como base el tópico de la atracción o amistad de lo semejante por lo semejante, que aparece formulado por vez primera en Homero (por ejemplo, en $\mathrm{Od}$. XVII 218: 'la divinidad lleva constantemente al semejante hacia su semejante'), y en algunos filósofos de la naturaleza (como Empédocles y Anaxágoras). ${ }^{15}$ Pero más allá del acuerdo parcial que Platón pueda llegar a tener con la postura de los poetas acerca de la amistad, y más allá del final aporético del Lisis, leemos en este pasaje la imprescindible apelación a la palabra autorizada de los poetas tradicionales a fin de examinar el problema de la philía. En una palabra, su requerimiento en tanto instrumentos de formación y guías del saber para todas las cuestiones de índole práctica. Tal gesto de apelación a su palabra autorizada se advierte asimismo en cada uno de los discursos sobre el Éros que ofrecen los selectos oradores del Banquete.

Volviendo a este último diálogo, Platón se detiene en la descripción minuciosa del proceso de poíesis de estos 'hijos espirituales', a saber, poemas, leyes e instituciones, por parte 
de poetas y legisladores célebres en estado de preñez, precisamente porque tales obras son más 'bellas e inmortales' que los 'hijos naturales' que ellos pudieran llegar a dar:

Cuando alguien se encuentra a su vez preñado en el alma de estas virtudes desde niño, inspirado como está por la divinidad (éntheos òn), ${ }^{16}$ al llegar a la edad conveniente desea ya parir y engendrar [...]. Y por tener contacto y trato con lo bello, alumbra y da vida a lo que tenía concebido desde antes; a su lado o separado de él se acuerda siempre de ese ser y con su ayuda cría en común con él el producto de su procreación, de tal manera que es una comunidad mucho mayor que la de los hijos la que tienen entre sí los de tal condición, y un afecto mucho más firme, ya que tienen en común hijos más bellos y más inmortales (kalliónon kaì athanatotéron paídon) (Symp. 209a8-c7). ${ }^{17}$

Cabe destacar en este pasaje una de las pocas -si no la única- menciones en el Banquete del tópico de la inspiración divina en relación con la poíesis, según el alma, de hijos espirituales, si bien la apelación a lo divino ya se había dejado entrever cuando Diotima hacía referencia a la procreación de hijos naturales:

Conciben todos los hombres, ¡Oh Sócrates!, no sólo según el cuerpo sino también según su alma, y una vez que se llega a cierta edad desea procrear nuestra naturaleza. Pero no puede procrear en lo feo sino tan sólo en lo bello. La unión de varón y de mujer es procreación y es una cosa divina (ésti dè toûto theîon tò prâg$m a)$, pues la preñez y la generación son algo inmortal que hay en el ser viviente, que es mortal (Symp. 206c1-8). ${ }^{18}$

\section{INSPIRACIÓN DIVINA Y LABOR POÉTICA EN APOLOGÍA, ION Y MENÓN}

Así como otros tópicos esenciales del platonismo, el de la inspiración poética ocupa un rol destacado dentro del conjunto de los diálogos. Abordado en diferentes períodos de su obra e inscripto en contextos temáticos disímiles, la apelación a la inspiración divina en relación con la labor poética describe un amplio arco que va desde la Apología a las Leyes, pasando por el Ion, Menón y Fedro. Detengámonos, a través de un somero repaso, en la Apología, Ion y Menón, sólo por atender a tres casos representativos en función de dicho tópico.

Los pasajes puntuales de la Apología que me interesa destacar se inscriben dentro del marco de la defensa de Sócrates ante las antiguas acusaciones que contribuyeron, según él, a crear desde antaño una falsa imagen de su persona, y sobre la cual se apoya la más reciente acusación legal y pública promovida por los acusadores Meleto, Ánito y Licón. La razón de su falsa imagen y de su creciente enemistad con importantes figuras de los círculos político-intelectuales atenienses se origina precisamente cuando da comienzo a una investigación (o misión divina, como él la denomina) que tiene por objeto poner a prueba la veracidad del mensaje oracular referido a su sabiduría (Apol. 21b8-c2; 21e5-22a1). Como es sabido, el blanco de su investigación fueron los representantes más reputados de las técnicas o saberes tradicionales de la época, es decir, los políticos, los poetas y los artesanos. Si bien, lejos de refutar, los resultados de su examen confirmaron aún más el pronunciamiento oracular, atendamos sobre todo al pasaje donde Sócrates relata su indagación acerca del presunto saber que detentaban los poetas en general: 
En efecto, tras los políticos me encaminé hacia los poetas, los de tragedias, los de ditirambos y los demás, en la idea de que allí me encontraría manifiestamente más ignorante que aquéllos. Así pues, tomando los poemas suyos que me parecían mejor realizados, les iba preguntando qué querían decir, para, al mismo tiempo, aprender yo también algo de ellos. [...] Por así decir, casi todos los presentes podían hablar mejor que ellos sobre los poemas que ellos habían compuesto (Apol. 22a8-b8).

Hasta aquí podría decirse que el tono general de la crítica es de corte epistémico, ya que desde la perspectiva de Platón nos enfrentamos ante una clase de creadores que, a pesar de referirse a diversos asuntos y de aparentar saber sobre todos los oficios, no pueden en rigor dar cuenta de ellos en sus obras; crítica en parte similar a la de República, con la salvedad de que en esta obra no aparece destacada, como en la Apología, la vía de la inspiración divina como respuesta al origen de ese saber, sino sólo una fuerte crítica al paradigma tradicional de poesía y, sobre todo, a Homero, su fundador. ${ }^{19}$ Pero además de esta crítica de corte epistémico, encontramos en la Apología el primer indicio del tópico de la inspiración divina en relación con la labor poética, tópico retomado más tarde en el Ión a partir de un examen del presunto saber del rapsodo o intérprete del poeta:

Así pues, también respecto a los poetas me di cuenta, en poco tiempo, de que no hacían por sabiduría lo que hacían, sino por ciertas dotes naturales y en estado de inspiración (enthousiázontes) como los adivinos y los que recitan los oráculos. En efecto, también éstos dicen muchas cosas hermosas, pero no saben nada de lo que dicen (Apol. 22b8-c3).
Lo que Platón objeta aquí no es tanto la inspiración divina que pudiera llegar a detentar un poetas (i.e. lo que da cuenta del discurso poético mismo), como el hecho de que, a causa de ella, se sienta habilitado para hablar acerca de otros asuntos y saberes que no entran dentro del área de su competencia: 'A causa de la poesía, creían también ser los más sabios de los hombres respecto de las demás cosas sobre las que no lo eran' (Apol. 22c5-6). Platón apela así a la antigua concepción de la inspiración divina no sólo para poder dar cuenta del origen del discurso poético, sino también a fin de explicar este exceso de corte epistémico en el que incurren los poetas. Porque el problema -y de allí la crítica- aparece justamente como consecuencia de este exceso, es decir, cuando los poetas trascienden los límites de su competencia o dominio específico, defecto que vuelve a repetirse en el caso de los artesanos, a quienes Sócrates reconoce también la posesión de un tipo particular de arte o técnica (téchne):

Estaba seguro de que encontraría a éstos [artesanos] con muchos y bellos conocimientos (pollà kaì kalà epistaménous). Y en esto no me equivoqué, pues sabían cosas que yo no sabía y, en ello, eran más sabios que yo. Pero, atenienses, me pareció a mí que también los buenos artesanos incurrían en el mismo error que los poetas: por el hecho de que realizaban adecuadamente su arte, cada uno de ellos estimaba que era muy sabio también respecto a las demás cosas, incluso las más importantes, y ese error oscurecía su sabiduría (Apol. 22d1-e1). ${ }^{20}$

Mientras que en el Ion se advierte, como veremos, una más clara negación del estatus técnico-epistémico de la labor de los poetas y rapsodas, junto con la consiguiente explicación del origen de sus obras a partir de la apelación 
a la inspiración divina, en la Apología, aun cuando no se llegue a poner en duda el valor positivo de sus obras en términos literarios y pedagógicos ('dicen muchas cosas hermosas'o 'muchos y bellos conocimientos'), Platón critica duramente a los poetas cuando, apoyándose en su dominio técnico específico, pretenden invadir otros asuntos y saberes sobre los cuales no detentan un conocimiento de la verdadera naturaleza de su objeto, ni son capaces de dar cuenta de las actividades que tales asuntos y saberes comprometen. ${ }^{21}$ Ello es lo que de alguna manera explica en los poetas tradicionales la coexistencia de sabiduría e ignorancia:

De modo que me preguntaba yo mismo, en nombre del oráculo, si preferiría estar así, como estoy, no siendo sabio en la sabiduría de aquellos ni ignorante en su ignorancia o tener estas dos cosas que ellos tienen (Apol. 22e1-4).

Otra muestra del valor de ejemplaridad positiva que detentan los poemas homéricos en este diálogo de juventud puede leerse en Apología 28b9-d5, donde Sócrates traza un marcado paralelo entre la ejecución, aun a riesgo de muerte, de su misión filosófica encomendada por el dios, con la que tuvieron en el pasado semidioses muertos en Troya tales como Aquiles, quien, sabiendo de antemano el destino trágico que le esperaba por boca de su madre Tetis, quiso dar muerte a Hector a fin de vengar a su amigo Patroclo. Para ello Platón cita aproximadamente el diálogo mantenido entre Tetis y Aquiles en $I l$. XVIII 96-104. Y en una línea similar son ejemplares las palabras de Sócrates en otro diálogo temprano como el Crat. 391c8-d1: 'Pues si no te satisfacen tampoco estas cosas, es preciso aprender de Homero y de los demás poetas'.

A diferencia, pues, de la mayor parte de los intérpretes que sólo resaltan el aspecto negativo o irónico de la referencia a los poetas tradicionales en la Apología-o, más aún, en el conjunto de los diálogos tempranos-, ${ }^{22}$ puede leerse esta obra a la manera de un reconocimiento de las virtudes y límites del discurso poético; pues no sólo vemos la primera apelación y análisis de la inspiración divina como su fuente, así como el resaltado de su valor positivo en términos literarios y pedagógicos, sino también los defectos en que tal discurso incurre cuando sobrepasa su dominio específico. En este sentido, si los poetas tradicionales no trascendieran los límites de su técnica específica, no habría problema alguno con ellos, puesto que es en ese punto donde se muestran como incompetentes. ${ }^{23}$

Sin entrar en profundidad, pasemos ahora al Ion para ver cómo vuelve a aparecer el tópico de la inspiración divina a la luz del examen del presunto saber o técnica del rapsoda, intérprete de la obra de los poetas. Aquí Platón, además de reflejar el estatus que detentaban los poetas y los rapsodas en la educación tradicional griega, aborda de forma específica el antiguo tema de la inspiración poética que recorre toda la literatura griega, y cuyas primeras apariciones encontramos en la invocación a las Musas que da inicio a los poemas homéricos y hesiódicos, y en Demócrito -es interesante recordar al respecto especialmente los fragmentos 18 ('Lo que un poeta escribe con entusiasmo e inspiración divina es, sin duda, bello') y 17 ('No se puede ser un gran poeta sin inflamación de ánimo y sin una especie de hálito de locura')- ${ }^{24}$ entre otras referencias previas. Como la mayor parte de los diálogos de juventud, el Ion se inscribe dentro del cuestionamiento socrático de los saberes tradicionales y, sobre todo, de los presuntos expertos que los detentaban y que circulaban con prestigio en el marco de la cultura ateniense de su tiempo. Si bien el blanco de su crítica son aquellos cantores o recitadores profesionales y ambulantes denominados 'rapsodas' 
(literalmente 'cosedores de cantos'), que no eran poetas sino más bien declamadores de poesía en las ciudades griegas y en los grandes festivales, el diálogo desemboca, en la medida en que los rapsodas oficiaban como meros intérpretes de los poetas, en un cuestionamiento del carácter técnico-epistémico del discurso poético y rapsódico. ${ }^{25}$

Partiendo del supuesto de que toda téchne-ya sea poética, pictórica, musical, médica, etc.- es un 'todo' en la medida en que implica un determinado género de investigación o dominio específico, Sócrates no se cansa de repetir a lo largo del diálogo que la capacidad o habilidad de Ion como rapsoda no se debe a una determinada ciencia (epistéme) o técnica (téchne), nociones empleadas aquí de forma indistinta (Ion 532c5-d3; 537c5-7). ${ }^{26} \mathrm{La}$ conclusión que se desprende y repite a lo largo del Ion es simple: la capacidad (dúnamis) del rapsoda para 'hablar tanto y tan bellamente sobre sus asuntos' (Ion 534b8-c1) no se deriva de una téchne o epistéme específica y sistemática-vinculada, como todo saber de esta clase, al campo del intelecto (nô̂s)-, sino que le acaece a la manera de un don, fuerza, poder, posesión o entusiasmo -por citar sólo alguno de los términos que aparecen como sinónimos a lo largo del diálogo- de origen divino (Ion 533d1-4). Si bien el examen gira en torno a la capacidad del rapsoda, en la medida en que él sólo representa un eslabón intermedio de la palabra del poeta, dicha conclusión terminará por afectar sobre todo la capacidad de éste último:

La Musa misma crea inspirados (enthéous), y por medio de ellos empiezan a encadenarse otros en este entusiasmo (enthousiazónton). De ahí que todos los poetas épicos, los buenos, no es en virtud de una técnica por lo que dicen todos esos bellos poemas, sino porque están endiosados y posesos (éntheoi kai katekh/chómenoi). Así también los poetas líricos hacen sus bellas composiciones no cuando están serenos (émphrones), sino cuando penetran en las regiones de la armonía y el ritmo poseídos por Baco, por un don divino, según el cual cada uno es capaz de hacer bien aquello hacia lo que la Musa le dirige; uno compone ditirambos, otro loas, otro danzas, otro epopeyas, otro yambos. En las demás cosas cada uno de ellos es incompetente» (Ion 533e3-534a4; 534b7-c5). ${ }^{27}$

Al ser su capacidad (dúnamis) de naturaleza divina, tanto el poeta como el rapsoda carecen de entendimiento $y$, por tanto, no pueden dar cuenta de los principios técnicos subyacentes a las acciones que describen en sus poemas. Se revelan, en una palabra, incompetentes en términos técnico-epistémicos; porque si fuera una técnica o ciencia la que los habilitase para hablar, deberían, en la medida en que sus poemas reflejan diversas temáticas y múltiples técnicas, hablar bien y con inteligencia de todas las cosas a las que hacen referencia. ${ }^{28}$ Homero, por ejemplo, hace alusión en sus poemas a diversas técnicas como la adivinación, la medicina, la del auriga, la pesca o la estrategia, entre otras, pero sin poder dar nunca cuenta de ellas en forma específica (Ion 538a5-b3; 540a5-6 ). Y sabemos, puesto que es una de las conclusiones más frecuentes en la mayor parte de los diálogos tempranos, que un saber que no alcanza a dar cuenta de sí mismo no constituye un auténtico saber. Como los poetas $y$, de forma indirecta, los rapsodas no pueden hablar con inteligencia respecto de todas las cosas sobre las que poetizan, ya que ni cuentan con un saber o técnica acerca de ellas ni tampoco pueden justificar cada una en su dominio específico, Sócrates concluye que el poeta no 
es un técnico, sino un inspirado, un enajenado o maniático; porque al igual que los profetas y adivinos, el poeta crea a partir de esta fuerza o entusiasmo divino que lo con-mueve. ${ }^{29}$ Pero esta conclusión que, desde un punto de vista epistémico, en tanto se apoya en la dicotomía inteligencia (noûs) - don divino (theía dýnamis o moíra), ${ }^{30}$ deslegitima la labor poética y rapsódica, abre al mismo tiempo la puerta para una de las apreciaciones positivas más elocuentes acerca de las obras de los poetas tradicionales dentro del corpus platónico, la cual constituye un claro antecedente del Fedro:

Porque es una cosa leve, alada y sagrada el poeta, y no está en condiciones de poetizar antes de que esté endiosado y sin razón (éntheós kai ékphron), y no habite ya más en él la inteligencia (noûs). Mientras posea este don, le es imposible al hombre poetizar y profetizar (Ion 534b3-7).

Platón refuerza esta visión positiva cuando, además de trazar un firme parentesco entre el poeta y lo divino, afirma que las obras de los grandes poetas tradicionales no sólo son numerosas, hermosas y de gran valor (Ion 534c7-d4), como dirá más tarde en Banquete y Fedro, sino que son en última instancia de factura divina (Ion 534e1-5).

Esta cuestión del origen divino del poema aparece presentada en el Ion mediante una de las más bellas metáforas que hallamos en el corpus platónico: la de la cadena (ormathós) de la inspiración divina, que engarza entre sí los eslabones o anillos (daktúlioi) representados por las Musas, el poeta, el rapsoda y, por último, el espectador, cadena por la cual fluye el mensaje poético impulsado por un entusiasmo divino (Ion 535e7-536b4). ${ }^{31}$ Mediante esta imagen de la cadena del entusiasmo divino, Platón busca opacar la conclusión negativa que se desprendía del examen del discurso de los poetas y rapsodas en clave técnico-epistémica. Es decir, nos abre aquí una nueva perspectiva que permite dar cuenta del discurso poético, ya no a partir de una técnica poética (téchne poietiké), sino como consecuencia de un entusiasmo de origen divino. Esta perspectiva volverá a aparecer resignificada en el Fedro a través de una distinción entre los estados de manía divina y cordura humana (Phaidr. 245a5-8), de la cual Platón desprende dos clases de poetas: eminentes (maniáticos) e imperfectos (cuerdos). ${ }^{32}$

En suma, si bien el Ion se apoya sobre la diferenciación entre un saber técnico organizado (téchne) que puede dar cuenta de sí mismo y un decir poético inspirado por la divinidad (theía moíra) que no sabe realmente lo que dice, cabe leer en este diálogo no sólo -y como habitualmente se lo hace- un claro cuestionamiento de la capacidad del poeta y del rapsoda en términos técnico-epistémicos, ${ }^{33}$ sino también un intento de explicar y de justificar el discurso poético desde otro punto de vista, vinculado al ámbito de lo divino, así como también de revalorizar las obras de los poetas tradicionales, en tanto ellas expresan muchas cosas excelentes, bellas, verdaderas, y de gran valor para la humanidad.

Al término de un diálogo de transición como el Menón, hallamos un planteo similar al del Ion en lo que toca a la explicación de la capacidad de los poetas, con la diferencia de que en el Menón la oposición básica se da entre las nociones de 'opinión verdadera' (dóxa alethés) y 'conocimiento' (epistéme), mientras que en aquel diálogo, como vimos, se da entre 'inteligencia' (nôิs) y 'don divino' (theía moíra). Partiendo de la base de que los políticos más célebres de su tiempo-como Temístocles, Arístides, Lisímaco, Pericles o Tucídides, entre otros- no adquirieron la excelencia (areté) a causa del conocimiento, cuyos rasgos esenciales son la estabilidad y la enseñabilidad ('si la 
virtud fuese un conocimiento, evidentemente sería enseñable' Men. 87c5-6), ya que si fuera así deberían habérsela podido enseñar a sus discípulos a fin de hacerlos virtuosos como ellos mismos, Sócrates concluye por tanto que tales políticos actúan bajo la guía de una opinión correcta o don divino, inestable e intransferible por definición (Men. 99b11-c5).

Volvemos a leer en Menón el clásico cuestionamiento socrático a los presuntos saberes, encarnado esta vez, como en la Apología, en la figura de los políticos tradicionales. Justamente me interesa el Menón en tanto incluye dentro del marco de este cuestionamiento otros discursos que, desde un punto de vista epistémico, no pueden, incluso expresando y llevando a buen término muchas y grandes obras verdaderas y bellas, dar cuenta de sí mismos, como es el caso del discurso de los poetas tradicionales, a quienes vuelve a emparentar, como ya lo había hecho en el Ion, con aquellos hombres y mujeres sabios en asuntos divinos, vates y adivinos:

Correctamente llamaríamos divinos a los que acabamos de mencionar, vates, adivinos y poetas todos, y también a los políticos, no menos que de ésos podríamos decir que son divinos e inspirados (theíous kai enthousiázein), puesto que es gracias al hálito del dios y poseídos por él, como con sus palabras llevan a buen fin muchos y grandes designios, sin saber nada de lo que dicen (Men. 99c11-d5).

La conclusión del diálogo reafirma el vínculo discurso político - opinión verdadera (o don divino), ${ }^{34}$ dejando aporéticamente planteada la posibilidad de una solución en tanto vuelva a priorizarse la pregunta por la esencia (qué es en sí la areté) que dio origen al diálogo, para a continuación indagar cómo la areté se da en los hombres, es decir, si es enseñable o no (Men. 99e4-100a2). En el caso puntual de los poetas, que es el que nos importa, es claro que la inspiración mediante la cual éstos dan forma a sus creaciones acontece -por lo que Platón viene afirmando desde diálogos anteriores- como un don imprevisible e inestable. Si bien en la crítica a los políticos de su tiempo, bajo el marco de la distinción opinión verdadera - conocimiento, Platón trae a colación la figura de los poetas tradicionales, no debemos pensar que lo que dice de aquéllos se ajusta completamente a lo que afirma sobre éstos. Porque, pensando en términos éticopolíticos, en el caso del obrar poético no resulta necesario que existan poetas capaces de hacer poetas también a los demás; contrariamente, en el caso del obrar político ello sí sería sumamente deseable, en función de la estabilidad y progreso de todo orden ético-político. Son, como es obvio, dominios diferentes que se vinculan en cuanto al origen (divino) del tipo de discurso, pero que tienen una incidencia claramente desigual en el orden de la pólis, lo que lleva a que el poeta divinamente inspirado pueda seguir explicando sin problemas su discurso en los términos de un don inestable e intransferible.

Otro dato positivo que se desprende del Menón es que así como Platón no descarta la presencia de la areté en hombres bellos y buenos, e incluso en grandes estadistas tanto de la actualidad como del pasado, tampoco la niega en los grandes poetas tradicionales, como es el caso puntual de Píndaro, de cuya obra Platón llega a citar un poema para apoyar la doctrina de la inmortalidad del alma ('Algo verdadero, me parece, y también bello dicen Píndaro y muchos otros de los poetas, cuantos son divinos', Men. 81a8-b2). Estos poetas se relacionan con aquellos estadistas no sólo en cuanto a la incapacidad de enseñar su respectiva areté a sus hijos o discípulos, sino también por el carácter bello y verdadero que poseen sus grandes obras políticas y poéticas. ${ }^{35}$ 


\section{HOMERO, HESÍODO Y 'LOS DEMÁS BUENOS POETAS’}

Tras esta breve panorámica, podemos observar el esbozo de una concepción positiva respecto de la figura y del estatus positivo de las obras de los poetas tradicionales, cuyo contorno, como vimos, va delineándose desde la Apología, Ion, Lisis y Menón, ${ }^{36}$ hasta desembocar, bajo la mediación del Banquete, en el Fedro. Es precisamente en este último diálogo donde, como señalamos al inicio, puede leerse una sistematización y complementación de la concepción de la poesía como inspiración divina, en cuya configuración los pasajes examinados de Banquete constituyen un eslabón clave. Tales pasajes, en efecto, permiten tender un puente hacia el planteo que Platón desarrollará en Fedro, ya que recién allí él terminará por sellar la alianza entre manía divina, poesía, belleza e inmortalidad, al afirmar que sólo en tal estado de manía o posesión divina el alma del poeta podrá llegar a crear bellas e inmortales obras (Phaidr. 244a6-8).

Cabe leer, pues, en los pasajes examinados del Banquete una clara valoración de las obras de los poetas tradicionales (Homero, Hesíodo y otros), que sigue en la línea de algunos diálogos platónicos tempranos y de transición, como Apología, Ion, Lisis y Menón:

Todo hombre preferiría tener hijos de tal índole a tenerlos humanos, si dirige su mirada a Homero, a Hesíodo o a los demás buenos poetas (toùs állous poietàs toùs agathoùs) y contempla con envidia qué descendencia han dejado de sí mismos, que les procura inmortal fama y recuerdo por ser ella también famosa e inmortal; o si quieres, agregó, hijos tales como los que ha dejado Licurgo en Lacedemonia, salvadores de Lacedemonia y, por decirlo así, de la Hélade. También Solón entre vosotros es honrado por haber dado vida a las leyes y muchos otros hombres [...], por haber mostrado muchas y bellas obras y haber engendrado toda clase de virtud (pollà kaì kalà érga, gennésantes pantoían aretén) (Symp. 209c7-e3). ${ }^{37}$

Casi al término de la Apología hallamos un pasaje similar, donde Sócrates, ya condenado y dirigiendo sus últimas palabras a los jueces que han votado por su absolución, revela su lectura esperanzada y positiva acerca de la muerte, cuyo bien se expresaría bajo dos alternativas: ya sea como una total ausencia de sensación (o un dormir sin soñar), ya sea como un viaje o cambio de morada del alma a fin de que ésta se encuentre en el Hades con todos los que han muerto y, entre otros, con los grandes e 'inmortales' (athánatoi) poetas del pasado con los que todo hombre desearía dialogar: '¿Qué bien habría mejor que éste, señores jueces? [...] Sería acaso malo el viaje. Además, cuanto daría alguno de vosotros por estar junto a Orfeo, Museo, Hesíodo y Homero?' (Apol. 40e6-41a7, c6-7). Tal como leemos en Banquete, los más reputados poetas y legisladores no sólo nos dejaron como legado muchas obras bellas e inmortales, ${ }^{38}$ razón por la cual se han instituido en su honor diversos cultos por haber tenido tales hijos espirituales y no naturales, sino que mediante tales obras lograron transmitir a la posteridad un catálogo de virtudes. ${ }^{39}$

Si bien hallamos en Banquete un reconocimiento explícito de las obras de los poetas tradicionales, cabe destacar también que sus productos constituyen, según Sócrates-Diotima, 'imágenes de areté' (eídola aretês), por contraposición al engendramiento o procreación de 'virtudes verdaderas' (aretaí alethê), propio del iniciado o filósofo que, eventualmente, pudiera llegar, 'de repente', ${ }^{40}$ a la revelación final de los 
grandes misterios narrados por Diotima, ${ }^{41}$ es decir, a la aprehensión de la Idea de belleza:

¿Es que no te das cuenta de que es únicamente en ese momento, cuando ve la belleza con el órgano con que ésta es visible, cuando le será posible engendrar, no imágenes de virtud, ya que no está en contacto con una imagen, sino virtudes verdaderas, puesto que está en contacto con la verdad (ouk eídola aretês, háte ouk eidólou ephaptoménoi, allà alethê, háte toû alethoûs ephaptoménoi); y de que al que ha procreado y alimenta una virtud verdadera le es posible hacerse amigo de los dioses y también inmortal, si es que esto le fue posible a algún otro hombre? (Symp. 212a2-7). ${ }^{42}$

Notemos aquí una diferencia importante respecto de la posición que Platón asumía en República. En efecto, allí el poeta tradicional, en tanto ubicado en un tercer grado ontológicoepistemológico en relación con la verdadera realidad (Idea de cama), no llegaba a engendrar, como en Banquete, una imagen de areté, sino más bien una 'imitación de una apariencia' (phantásmatos mímesis). En este sentido, la novedad del planteo del Banquete residiría en que, al engendrar el poeta tradicional una imagen de areté (y no una imitación de una apariencia), puede ubicárselo, siguiendo la jerarquía ontológica-epistemológica tripartita de República X leída desde el Banquete, en un segundo nivel respecto de la verdad (poeta de segundo grado), mientras que en República Homero y los demás poetas tradicionales aparecen tipificados peyorativamente como poetas de 'tercer grado'.43

Detengámonos, por último, en la concepción del poeta tragicómico como modelo del verdadero artista, que leemos casi al término del Banquete, puesto que en ella cabe leer otra clara revalorización de la tradición poética en términos positivos. En dicha ocasión, Aristodemo -vía Apolodoro- rememora:

Pero lo capital fue que Sócrates les obligó [a Agatón y Aristófanes] a reconocer que era propio del mismo hombre saber componer comedia y tragedia, y que quien con arte es poeta trágico también lo es cómico (Symp. 223d2-6). ${ }^{44}$

La pregunta que se desprende naturalmente de este pasaje es: ¿quién, de entre los selectos oradores participantes del encomio a Éros, encarna en el Banquete a ese hombre capaz de componer tragedia y comedia a la vez? Aquí pueden arriesgarse algunas opciones interpretativas respecto de esta última escena protagonizada por Sócrates, Agatón y Aristófanes: o bien para Sócrates el más claro exponente de su concepción del artista es Aristófanes; $;^{45} \mathrm{O}$ por el contrario, en la medida en que el poeta trágico Agatón consideraba que su encomio a Éros tenía 'parte de broma y parte de comedida gravedad' (Symp. 197e7-8), es este poeta el más fiel representante de la definición socrática del artista; o, en tanto eran obligados por Sócrates a admitir tal concepción, ni Agatón ni Aristófanes la representan ya que cada uno de ellos se desempeña con soltura sólo dentro de su género respectivo, y no en ambos a la vez; o bien Sócrates esgrime su definición del artista ideal ante estos dos poetas (y no ante otros) porque veía que ellos eran, en potencia, los que podían llegar a poner en acto tal concepción. $\mathrm{O}$, por último, también podría pensarse que la concepción socrática no es más que una referencia indirecta a Platón mismo, pues al fin y al cabo es éste quien, al escribir el Banquete, logró hacer interactuar en este diálogo diferentes géneros discursivos, entre ellos el trágico y el cómico, y 
quien a través de tal interacción dio cuenta de un nuevo perfil de poeta y de cierta intención reformadora en la cultura teatral ateniense de la época. ${ }^{46}$ No es nuestra intención abonar aquí alguna de tales opciones interpretativas -todas éstas plausibles y con suficiente apoyo textual-, sino más bien destacar que no se trata de un hecho casual que Aristófanes y Agatón, dos representantes de la tradición poética, sean los únicos oradores que se quedan, al término de la velada, despiertos y platicando con Sócrates acerca de los atributos que caracterizan a un verdadero artista.

\section{CONCLUSIÓN}

Como señalamos al comienzo del artículo, en el Fedro la poesía terminará siendo pensada en función de la siguiente serie conceptual: $m a$ nía divina, belleza e inmortalidad. Pero vimos aquí cómo Platón, previamente en Banquete, ya había atisbado las condiciones de posibilidad para dicha serie, al establecer una estrecha vinculación entre las nociones de éros, poíesis e inmortalidad. Esta forma de concebir la poesía supone un claro contraste con la concepción negativa acerca del paradigma poético tradicional que Platón asume en los libros II, III y X de República, paradigma cuyos rasgos cabe recordar de forma somera y esquemática, dado que ello excede los límites de nuestro análisis. El paradigma poético tradicional implicaba para Platón, en efecto, una mímesis de caracteres y conductas malas tanto del orden humano como del divino; imágenes del vicio (kakías eikósi) que terminaban por sembrar en las almas de los niños y jóvenes disvalores como la cobardía, la intemperancia, la mezquindad, la blandura y avidez de riquezas. Además de detentar una presunta omnisciencia acerca de todos los oficios, el poeta tradicional buscaba reflejar en sus obras el lenguaje del hombre ordinario, apelando para ello a la dimensión cosmética del lenguaje (Rep. II 369b5-374d7), ${ }^{47}$ es decir, a un estilo pictórico, ornamentado y puramente imitativo - de allí las reiteradas analogías y desplazamientos entre la figura del pintor y la del poeta tradicional, o, en los términos del Sofista, entre fabricantes de simulacros visuales y verbales-, cuyo poder hechiza las almas de sus destinatarios amarrándolas al ámbito de lo visible, sensitivo y emotivo, e impidiendo así su elevación a lo racional.

Sobre la base de las cuatro dimensiones (religiosa, ético-política, ontológico-epistemológica y psicológica) en torno a las cuales hace girar su crítica al paradigma poético tradicional, Platón prescribe, por contraste y a grandes rasgos, una serie de pautas que deberá plasmar en sus obras el nuevo tipo de poeta proyectado para la pólis ideal de República, a fin de componer una poesía austera, bella y saludable (Rep. III 401c4-d3). En términos religiosos, el poeta deberá imitar la divinidad como esencialmente buena (sólo causa del bien), simple, inmutable, y veraz en palabras y obras; ${ }^{48}$ alabar en sus composiciones el Hades; suprimir quejas, lamentos, risas exageradas y todo tipo de debilidades en boca de dioses, héroes y hombres de bien, y dejar de representar a los injustos como felices y a los justos como desgraciados. En términos éticopolíticos, deberá imitar sólo los modelos de carácter y conducta de los hombres de bien. En términos ontológico-epistemológicos, se ocupará de realizar una imitación de la verdad (más que de una apariencia), es decir, una mímesis con conocimiento de los caracteres virtuosos, $\mathrm{o}$, en su defecto, con una 'opinión recta' (poeta de segundo grado o nivel) que implique algún tipo de comunicación con el filósofo guardián que detenta la epistéme y, justamente por ello, 'utiliza' correctamente las obras poéticas en términos pedagógico-políticos. En términos psicológicos, 
deberá imitar el elemento logistikón del alma, a fin de promover la regulación y moderación de los impulsos irracionales ligados al deseo y la ira, privilegiando un modelo de conocimiento que procura ir más allá del mero testimonio de los sentidos, dando lugar así a la unidad y el dominio de sí. En términos formales o estilísticos, el poeta procurará expresarse a través de un estilo austero, menos agradable que el puramente imitativo -tragedia y comedia-, a saber: el estilo narrativo mixto (en el que la imitación ocupa una pequeña parte con respecto a largos trozos de narración); deberá seguir, en una palabra, el marco ya establecido por el género de los himnos a los dioses y los encomios de los héroes. ${ }^{49}$

No sólo es distinto, por tanto, el punto de vista desde el cual se enfoca la poesía tradicional en Banquete y República, sino también la cuestión de los criterios de composición que priman en tales diálogos: mientras que en Banquete Platón le asigna una mayor preeminencia al criterio 'estético' vinculado al aspecto agradable o seductor de la obra poética, en República puede advertirse un mayor énfasis puesto en el criterio utilitarista, ligado a lo útil o provechoso de aquélla, esto es, a su corrección ético-política (Rep. X 607e1-2) en función del mejoramiento de los regímenes políticos y la vida humana. ${ }^{50}$ En suma, Platón reconoce en Banquete -y posteriormente en Fedro- su profundo respeto por el linaje de la tradición poética griega y, sobre todo, por su importante función social y educadora para la posteridad, dejando en claro que el punto de vista desde el cual piensa allí la poesía tradicional no es exactamente el mismo que el de República. Al no encuadrarse dentro de un proyecto de reforma filosófico-política de la pólis, podemos desprender del Banquete una valoración positiva de aquellos representantes de la poesía tradicional que en República Platón se disponía a excluir por las razones -de índole religiosa, ético-política, ontológico-epistemológica y psicológica- mencionadas.

\section{REFERENCIAS BIBLIOGRÁFICAS}

\section{EDICIONES, TRADUCCIONES Y COMENTARIOS:}

Allen 1991: R.E. Allen, Plato, The Symposium, Yale University Press, New Haven 1991.

Bluck 1964: R.S. Bluck, Plato, Meno. A Commentary, Cambridge University Press, Cambridge 1964.

Brisson 1989: L. Brisson, Platon, Phèdre, GF - Flammarion, Paris 1989.

Brisson 1998: L. Brisson, Platon, Le Banquet, GF Flammarion, Paris 1998.

Brisson 1997: L. Brisson, Platon, Apologie de Socrate, GF - Flammarion, Paris 1997.

Burnet 1900-1907: J. Burnet, Platonis Opera, Clarendon Press, Oxford 1900-1907, 5 vols.

Bury 1932: R.G. Bury, The Symposium of Plato, W. Heffer and Sons, Cambridge 1932.

Canto-Sperber 1989: M. Canto-Sperber, Platon, Ion, GF - Flammarion, Paris 1989.

Dover 1980: K.J. Dover, Plato, Symposium, Cambridge University Press, Cambridge 1980.

Gil 1983: L. Gil, Platón, El banquete, Fedón, Fedro, Orbis, Buenos Aires 1983.

Jowett, 1953 [1892]: B. Jowett, The Dialogues of Plato, $4^{\mathrm{a}}$ ed. de D.J. Allan y H.E. Dale, Clarendon Press, Oxford 1953 [1892], 4 vols.

Leroux 2002: G. Leroux, Platon, La République, GF Flammarion, Paris 2002.

Lucas 1968: D.W. Lucas, Aristotle Poetics, Clarendon Press, Oxford 1968.

Pabón - Fernández-Galiano 1949: J. Pabón - M. Fernández-Galiano, Platón, La República, Instituto de Estudios Políticos, Madrid 1949, 3 vols.

Robin 1933: L. Robin, Platon, Phèdre, en Oeuvres Complètes, Les Belles Lettres, Paris 1933, tome IV, 3.

Rosen 1968: S. Rosen, Plato's Symposium, Yale University Press, New Haven 1968.

Rowe 1986: C.J. Rowe, Plato, Phaedrus, Aris \& Phillips Ltd., Warminster 1986.

Rowe 1998: C.J. Rowe, Plato, Symposium, Aris \& Phillips Ltd., Warminster 1998.

Santa Cruz - Crespo 2007: M.I. Santa Cruz - M.I. Crespo, Platón, Fedro, Losada, Buenos Aires 2007. 


\section{ESTUDIOS:}

Asmis 1992: E. Asmis, 'Plato on Poetic Creativity', in R. Kraut (ed.), The Cambridge Companion to Plato, Cambridge University Press, Cambridge 1992, 338-364.

Belfiore 1983: E. Belfiore, 'Plato's Greatest Accusation against Poetry', in F.J. Pelletier - J. King-Farlow (eds.), New Essays on Plato, Canadian Journal of Philosophy, 1983, suppl. vol. 9, 39-62.

Brandwood 1990: L. Brandwood, The Chronology of Plato's Dialogues, Cambridge University Press, Cambridge 1990.

Casertano 2013: G. Casertano, 'La difficcile analogia tra poesia e amore', in Proceedings of X Symposium Platonicum: The Symposium, Università di Pisa, Pisa 2013, vol. I, 365-370.

Clay 1975: D. Clay, 'The tragic and comic poet of the Symposium', "Arion» 2 (1975), 238-261.

Collingwood 1925: R.G. Collingwood, 'Plato's Philosophy of Art', «Mind» 34 (1925), 154-172.

Collingwood 1938: R.G. Collingwood, The Principles of Art, Clarendon Press, Oxford 1938.

Cook 1996: A. Cook, 'Plato and Poetry', in The Stance of Plato, Littlefield Adams Books, Boston 1996, 75-97.

Cornford 1967: F.M. Cornford, 'La doctrina de éros en el Banquete de Platón', en La filosofía no escrita, Ariel, Barcelona 1974, 129-146.

Corrigan - Glazov-Corrigan 2004: K. Corrigan - E. Glazov-Corrigan, Plato's Dialectic at Play: Argument, Structure, and Myth in the Symposium, The Pennsylvania State University Press, Pennsylvania 2004.

Chandran Madhu 1999: R. Chandran Madhu, 'Plato's Homer, «Ancient Philosophy» 19 (1999), 87-95.

Delatte 1934: A. Delatte, Les conceptions de l'enthousiasme chez les philosophes présocratiques, Les Belles Lettres, Paris 1934.

Dodds 1951: E.R. Dodds, Los griegos y lo irracional, Alianza, Madrid 1980.

Dover 1965: K.J. Dover, 'The date of Plato's Symposium', «Phronesis» 10 (1965), 2-20.

Dover 1966: K.J. Dover, 'Aristophanes' speech in Plato's Symposium', "Journal of Hellenic Studies» 86 (1966), 41-50.

Else 1986: G.F. Else, Plato and Aristotle on Poetry, University of North Carolina Press, Chapel Hill 1986.

Estiú 1982: E. Estiú, 'La concepción platónica-aristotélica del arte: Técnica e imitación', «Revista de Filosofía» 24 (1982), 7-26.

Ferrari 1992: G.R.F. Ferrari, 'Platonic love', in R. Kraut (ed.), The Cambridge Companion to Plato, Cambridge University Press, Cambridge 1992, 248-276.

Friedländer 1964: P. Friedländer, Plato, Routledge \& Kegan Paul, London 1964, vol. II.

Gadamer 1934: H.-G. Gadamer, 'Plato und die Dichter', in Griechische Philosophie I, Gesammelte Werke, J. C. B. Mohr (Paul Siebeck), Tübingen 1985, Band 5, 187-211.

Gadamer 1977: H.-G. Gadamer, Verdad y método I, Sígueme, Salamanca 1977.

Greene 1918: W.C. Greene, 'Plato's View of Poetry', «Harvard Studies in Classical Philology» 29 (1918), 1-75.

Giuliano 2005: F.M. Giuliano, Platone e la poesia. Teoria della composizione e prassi della ricezione, Academia Verlag, Sankt Augustin 2005.

Guthrie 1975: W.K.C. Guthrie, Historia de la filosofía griega, Gredos, Madrid 1990, vol. IV.

Grube 1973: G.M.A. Grube, El pensamiento de Platón, Gredos, Madrid 1973.

Hackforth 1950: R. Hackforth, 'Immortality in Plato's Symposium', «Classical Review» 64 (1950), 42-45.

Halliwell 2002: S. Halliwell, The Aesthetics of Mimesis. Ancient Texts and Modern Problems, Princeton University Press, Princeton 2002.

Hartland-Swan 1951: J. Hartland-Swan, 'Plato as Poet: A Critical Interpretation', «Philosophy» 96-97 (1951), 3-18, 99-141.

Hyland (1968): D. Hyland, 'Éros, epithymía and philía in Plato’, «Phrónesis» 13 (1968), 32-46.

Heidegger 1961: M. Heidegger, Nietzsche I, Destino, Barcelona 2000.

Isnardi Parente 1966: M. Isnardi Parente, Techne. Momenti del pensiero greco da Platone ad Epicuro, La Nuova Italia, Firenze 1966.

Jaeger 1957: W. Jaeger, Paideía: los ideales de la cultura griega, Fondo de Cultura Económica, México 1957.

Leszl 2004: W.G. Leszl, 'Plato's attitude to poetry and the fine arts and the origins of aesthetics', in Études platoniciennes, Les Belles Lettres, Paris 2004, vol. I, 113-197.

Lesky 1957-1958: A. Lesky, Historia de la literatura griega, Gredos, Madrid 1968.

Menza 1972: V. Menza, 'Poetry and the Technê Theory: An Analysis of the Ion and Republic, Bks. III and X', diss., Johns Hopkins University 1972, 263-284. 
Moravcsik - Temko 1982: J.M.E. Moravcsik - P. Temko (eds.), Plato on Beauty, Wisdom, and the Arts, Rowman \& Littlefield, Totowa 1982.

Murdoch 1977: I. Murdoch, El fuego y el sol. Por qué Platón desterró a los artistas, Fondo de Cultura Económica, México 1982.

Murray 1981: P. Murray, 'Poetic Inspiration in Early Greece', «Journal of Hellenic Studies» 101 (1981), 87-100.

Nehamas 1988: A. Nehamas, 'Plato and the Mass Media', in Virtues of Authenticity. Essays on Plato and Socrates, Princeton University Press, Princeton 1999, 279-299.

Nichols 2004: M.P. Nichols, 'Socrates' Contest with the Poets in Plato's Symposium', "Political Theory» 32 (2004), 186-206.

Nightingale 1995: A.W. Nightingale, Genres in Dialogue. Plato and the Construct of Philosophy, Cambridge University Press, Cambridge 1995.

Nussbaum 1986: M.C. Nussbaum, La fragilidad del bien. Fortuna y ética en la tragedia y la filosofía griega, Visor, Madrid 1995.

Patterson 1982: R. Patterson, 'The Platonic art of comedy and tragedy', "Philosophy and Literature» 6 (1982), 76-93.

Ricoeur 1965: P. Ricoeur, Freud: una interpretación de la cultura, Siglo XXI, México 1970.

Riegel 2013: N. Riegel, 'Tragedy and Comedy at Agathon's Party: Two Tetralogies in Plato's Symposium', in Proceedings of X Symposium Platonicum: The Symposium, Università di Pisa, Pisa 2013, vol. I, 277-282.

Rodrigo 2001: P. Rodrigo, 'Platon et l'art austère de la distanciation', in M. Fattal (ed.), La philosophie de Platon, L'Harmattan, Paris 2001, 139-165.

Rodríguez Adrados 1969: F. Rodríguez Adrados, 'El Banquete platónico y la teoría del teatro’, «Emérita» 37 (1969), 1-28.

Stern-Gillet 2004: S. Stern-Gillet, 'On (mis)interpreting Plato’s Ion’, «Phronesis» LXIX (2004), 169-201.

Stokes 1993: M.C. Stokes, 'Symposium 172a-c: a Platonic phallacy?', «Liverpool Classical Monthly» 18 (1993), 128.

Tatarkiewicz 1960-68: W. Tatarkiewicz, Historia de la Estética I. La estética Antigua, Akal, Madrid 1987.

Tatarkiewicz 1976: W. Tatarkiewicz, Historia de seis ideas. Arte, belleza, forma, creatividad, mímesis, experiencia estética, Tecnos, Madrid 1986.
Tigerstedt 1969: E.N. Tigerstedt, Plato's Idea of Poetical Inspiration, Commentationes Humanarum Litterarum Societas Scientiarum Fennicae, Helsinki (1969), 44, 2.

Verdenius 1962: W.J. Verdenius, 'Der Begriff der Mania in Platons Phaidros', «Archiv für Geschichte der Philosophie» 44 (1962), 132-150.

Vernant 1965: J.-P. Vernant, 'Observaciones sobre las formas y los límites del pensamiento técnico en los griegos', in J.-P. Vernant, Mito y pensamiento en la Grecia antigua, Ariel, Barcelona 1973, 280-301.

Vicaire 1960: P. Vicaire, Platon: Critique littéraire, Klincksieck, Paris 1960.

Villela-Petit (1991): M. Villela-Petit, 'La question de l'image artistique dans le Sophiste', in P. Aubenque et M. Narcy (eds.), Etudes sur le Sophiste de Platon, Bibliopolis, Napoli 1991, 55-90.

Vlastos 1973: G. Vlastos, 'The Individual as an Object of Love in Plato's dialogues', in G. Vlastos, Platonic Studies, Princeton University Press, Princeton 1973, 3-42.

Warry 1962: J.G. Warry, Greek Aesthetic Theory. A Study of Callistic and Aesthetic Concepts in the Works of Plato and Aristotle, Metheun, London 1962.

Wilamowitz-Moellendorff 1919: U. WilamowitzMoellendorff, Platon, Weidmannsche, Berlin 1919, 2 vols

\section{NOTES}

1 Para este contraste entre el carácter divino atribuido al Éros en Fedro y la insistencia por parte de Diotima en la negación de tal carácter en Banquete, cf., entre otros, Guthrie 1975, 386, nota 192, quien no ve la necesidad de excusar a Sócrates por llamar a Éros en Fedro un dios y en el Banquete un daímon: 'Allí le venía bien a su propósito hacer al Amor un intermedio y un intermediario, y adaptó en consonancia la mitología popular; aquí la puede aceptar sin alteraciones. Jugar de esta manera con los mitos era un recurso literario común, que emplean con entera libertad los otros interlocutores del Banquete'. Véase en la misma línea Nussbaum 1986, 282, y Ferrari 1992, 262- 268

2 Como ejemplo de los efectos negativos (i.e. vileza, insensatez, intemperancia, engaño, esclavitud, entre otros) propios del estado de manía en algunos diálogos previos al Fedro, véase especialmente Men. 91c3, Crat. 404a4, Symp. 213d, 215c-e, y Rep. I 329c, II 382c8-e3, III 400b2, 403a7-11, VII 539c6, IX 573a-b. Para la oposición entre 
manía y sophrosýne, cf., entre otros pasajes, Prot. 325b5. Verdenius 1962, 137 destaca en este sentido la contraposición entre el amor 'sensato' y 'moderado' ponderado en Rep. III 403a7-11, V 474d-e (la descripción de los efectos nocivos del amor desmedido) y Leg. V 731e5-732al ('En efecto, el que ama se enceguece respecto de lo amado, de modo que juzga mal lo justo, lo bueno y lo bello, porque piensa que siempre debe preferir lo suyo a lo verdadero'), y el 'enloquecido' alabado en Fedro.

3 Desligada de las razones intelectuales y éticas, la teoría de la posesión divina se revela en Fedro como una explicación alternativa de la capacidad de los poetas tradicionales. Cf. al respecto Guthrie 1975, 206.

4 Sobre la fecha de composición del Banquete, se piensa en general que la obra es anterior al Fedro, y aproximadamente contemporánea de República y Fedón. Para este punto, cf., entre otros, Dover 1965, 2-20, y Brandwood 1990.

5 Sobre el uso platónico de la citación poética, véase asimismo en este sentido Cook 1996, 75-76, y Vicaire 1960, 77-149, 158-192; y, más puntualmente sobre el Homero de Platón, cf. especialmente Chandran Madhu 1999, 87-95. 6 Nusbbaum 1986, 41.

7 Para un análisis específico de esta analogía entre poíesis, poesía y éros, cf. especialmente Casertano 2013, 366-370. 8 Para este uso genérico de poíesis, poiéma y poietés, cf., entre otros, Lucas 1968, 54.

9 En Soph. 219a10-b12, Platón vuelve a ofrecer, en el contexto de la distinción entre dos tipos de técnicas (adquisitiva y productiva) dentro de las cuales busca encuadrar al sofista, una definición del término 'poíesis' acotada al ámbito de la mímesis, definición según la cual poíesis representa un cierto tipo de producción de imágenes, y no de realidades individuales.

10 Heidegger 1961, 160.

$11 \mathrm{Al}$ referirse a las leyes nupciales, Platón vuelve en Leyes IV 721b6-c6 sobre esta idea central del Banquete 206b1208 b6 acerca de la participación de lo mortal en lo inmortal por medio de la generación, o de la procreación como la única inmortalidad alcanzable. Sobre este punto, cf. especialmente Hackforth 1950, 42-45, y Cornford 1967, 137. Si bien Platón suscribe en Banquete la participación de lo mortal en lo inmortal a través de la procreación físico-espiritual, ello no significa que lo mortal represente la inmortalidad del mismo modo que lo representa lo divino. Guthrie 1975, 374-375, y la mayor parte de los intérpretes, destacan aquí una clara contraposición platónica entre la inmortalidad temporal (o secundaria) y la vida eterna.

12 Según Cornford 1967, 133, Platón emplea el término éros para referirse al impulso del deseo en todas sus formas. En este sentido es concebido como una fuerza única o caudal de energía, que se dirige según canales divergentes y hacia metas que varían.

13 Sobre esta ambigüedad del término philía (y derivados) en Lisis y su relación con éros, cf. especialmente Hyland 1968, 32-46.

14 Respecto de esta apelación a los poetas tradicionales como guías, véase Cook 1996, 79.

15 Este tópico aparece de forma frecuente en el corpus platónico. Entre otras referencias, véase Gorg. 510b2-4, Symp. 195b5, Rep. I 329a2-4, Leg. IV 716c2-4; y asimismo Aristóteles, EN IX 3, 1165b 16-17.

16 Nos apartamos aquí, como la mayor parte de los traductores del Symposium (Brisson, Allen, Gil, Martínez Hernández, entre otros), de la lectura de Burnet, según la cual debe leerse étheos (joven, mancebo, célibe, soltero), en vez de én-theos (poseído o inspirado por un dios). 17 Véase en una línea similar Phaidr. 258b10-c5: ‘¡Y qué? Cuando un orador o un rey, habiendo conseguido el poder de un Licurgo o de un Solón o de un Darío, se hace inmortal logógrafo en la ciudad, ¿̇acaso no se piensa a sí mismo como semejante a los dioses, aunque aún viva, $\mathrm{y}$ los que vengan detrás de él no reconocerán lo mismo, al mirar sus palabras escritas?'. Sobre los progenitores de estos hijos espirituales, afirma Cornford 1967, 139: 'De tal suerte son los poetas y los artistas creadores, cuyas obras sobreviven y transmiten a la posteridad sus pensamientos. Incluso el educador engendra hijos de clase más hermosa y duradera, al plantar sus ideas en esas mentes vivas en donde vivirán otra vez, para engendrar de nuevo otras generaciones de hijos espirituales. Y junto al educador se coloca el legislador-Licurgo o Solón-, los cuales dejan leyes e instituciones como medios permanentes de ejercitar a sus conciudadanos en la virtud'. Para el tema de la unidad esencial de la poética y la erótica en Banquete, cf. Ricoeur 1965, 455.

18 Giuliano 2005, 216-218 lee la doctrina del 'entusiasmo poético' en el Banquete a la luz del retrato de Sócrates presentado por Alcibíades en su discurso.

19 Recordemos al respecto dos pasajes de República X en donde Platón resaltaba, dentro del marco de la dimensión epistemológica de su crítica a la poesía tradicional, el carácter omnisciente que aparenta el poeta: 'Así, decimos que el pintor nos pintará un zapatero, un carpintero y los demás artesanos, sin entender nada de las artes de estos hombres; y no obstante, si es buen pintor, podrá, pintando un carpintero y mostrándolo desde lejos, engañar a niños y hombres necios, haciéndoles creer que es un carpintero de verdad. [...] Y creo, amigo, que sobre todas estas cosas nuestro modo de pensar ha de ser el siguiente: cuando alguien nos anuncie que ha encontrado un hombre entendido en todos los oficios y en todos los asuntos que cada uno en particular conoce, y que lo sabe todo más perfectamente que cualquier otro, hay que responder a ese tal que es un simple y que probablemente ha sido engañado al topar con algún charlatán o imitador, que la ha parecido omnisciente (pánsophos) por no ser él capaz de distinguir la ciencia, la ignorancia y la imitación' (Rep. 598b8-d5). Sobre esta confusión que el imitador provoca en la audiencia, cf. especialmente Belfiore 1983, 44-45. 20 Sobre el término téchne en los griegos y su relación con lo que nosotros denominamos 'arte', cf. Tatarkiewicz 1960-68, 31; 1976, 80, para quien, en tanto se trata de habilidad productiva mental y manual, debe traducirse como 'maestría' o 'técnica', a fin de resaltar la amplia gama de oficios y de técnicas que englobaba tal término para los griegos; Heidegger 1961, 85, 160, Collingwood 1938, 6, Warry 1962, 52-57 y Gadamer 1977, 53, 386, quienes destacan 
en la misma línea la discrepancia que existe entre nuestro sentido eminente de 'arte', ya separado del contexto de práctica productiva (sobre todo a partir de la emergencia de la estética como disciplina filosófica en el siglo XVIII), y el que tenían los griegos. Respecto de la historia de dicha noción como saber práctico organizado desde Homero a Platón, cf. especialmente Isnardi Parente 1966, 1-6. Para un resumen de los rasgos fundamentales que determinan la estructura de una téchne, cf. Jaeger 1957, 517, y Nussbaum 1986, 143-145.

21 Sobre la conveniencia de que cada uno se dedique al oficio que le es propio, y no se inmiscuya en territorios ajenos, sobre todo los vinculados a la 'técnica política' (politikè téchne), es ilustrativo un pasaje del Protágoras en el cual Sócrates se dirige al personaje homónimo que sostiene la enseñabilidad de la areté. Es precisamente este trapasar la esfera de la técnica específica o, en términos de República, la violación misma del principio de la especialización de las funciones, lo que Platón critica duramente a los poetas (al igual que a la clase política), puesto que, sin saber, se refieren en sus obras a cuestiones que atañen, entre otras, al gobierno de las ciudades. Recordemos al respecto, entre otros pasajes paradigmáticos, Rep. X 598b6-d5.

22 Como ejemplo de esta opinión predominante, véase, entre otros, Collingwood 1925, 164-167, Schaerer 1930, 136, y Guthrie 1975, 93, 201. Para este último intérprete, tales alusiones a los poetas inspirados por la divinidad deben leerse en clave irónico-negativa, lo cual lo lleva a contraponer sin justificación los planteos de la Apología y del Ion sobre la inspiración divina con el de la manía poética del Fedro. Estiú 1982, 21-26 hace referencia al aspecto negativo de la doctrina platónica de la inspiración divina entendida como ignorancia, si bien reconoce en Fedro un 'aspecto positivo' de ella, en tanto compromete un 'saber supra-racional'; Nussbaum 1986, 297-300, por su parte, considera que en los diálogos tempranos sólo cabe hablar de una caracterización negativa de la labor inspirada de los poetas tradicionales. Sobre el Ion como un temprano ataque a la poesía, cf. más recientemente Stern-Gillet 2004, 199.

23 Para la actitud ambivalente de Platón respecto de la poesía en Apología, véase especialmente Halliwell 2002, 39-40.

24 Respecto de las teorías de Demócrito sobre la inspiración y su estrecha relación con la concepción platónica de la posesión divina del poeta, cf., entre otros, Delatte 1934, 28-79, Dodds 1951, 87 y Giuliano 2005, 177-183. Para un análisis exhaustivo de la idea de inspiración poética en la literatura griega arcaica (de Homero a Píndaro), cf. especialmente Murray 1981, 87-89, 99-100, quien suscribe la tesis de que antes de Platón tal idea no implica necesariamente posesión o locura extática, ni incompatibilidad con el arte o la téchne. Subraya en este sentido que recién a partir de Platón el concepto de inspiración poética pasa a ser entendido como sinónimo de enthousiasmós o manía, y a oponerse por tanto al de téchne.

25 La opinión de los intérpretes varía respecto del blanco al que estaría apuntando la crítica platónica en el Ion.
Para algunos, en efecto, la mira está puesta sólo en el personaje homónimo, un rapsoda caracterizado como pretencioso y banal; otros consideran que se refiere a los rapsodas en general, pero no a los poetas; y para otra línea interpretativa Platón se sirve de los rapsodas para hacer referencia a los poetas (cf. Tigerstedt 1969, 21); por último, están los que sostienen que el objeto de la crítica implica tanto los poetas (especialmente Homero) como sus panegiristas (Guthrie 1975, 205, nota 261). Siguiendo esta última línea de lectura, Sócrates interroga en el Ion el presunto saber del soberbio rapsoda homónimo, experto sólo en materia de Homero, retomando aquel tipo de investigación (o misión divina) que en la Apología dirigió hacia los políticos, poetas y artesanos, a los cuales ya interrogaba con el fin de refutar el mensaje oracular según el cual él era el más sabio de todos los atenienses.

26 La equivalencia o sinonimia entre epistéme y téchne (así como entre epistémon-conocedor, entendido-y technites -artista, artesano-) no sólo se repite a lo largo del Ion (cf. 541e1-2, entre otros pasajes), sino también en otros diálogos como en Rep. IV 438c6-e8 y Polit. 295d7e1, 300e7-9, donde arte real (basiliké téchne) y ciencia política (politiké epistéme) son equiparados. Respecto de esta indistinción entre téchne y epistéme en Platón, cf., entre otros, Jaeger 1957, 515, y Nussbaum 1986, 142. 27 Para un análisis de este pasaje, cf. especialmente Cook $1996,82$.

28 Sobre este contraste entre el saber de los artesanos y la ignorancia propia de los imitadores, cf. Menza 1972, 263-264, 282-284, y Moravcsik 1982, 29-46, quien señala que el imitador difiere del artesano en que desconoce las especificaciones funcionales de los objetos que representa. Nussbaum 1986, 274, por su parte, explica dicha imposibilidad epistémica del poeta a la luz de los efectos que la inspiración divina ejerce sobre éste.

29 Sobre las formas que asume el pensamiento técnico en los griegos, cf. especialmente Vernant 1965, 280 301, quien analiza la delimitación de una concepción racional de la téchne entre los siglos VII y V a. C., la cual implica su progresiva desvinculación de lo mágico y de lo religioso. Según este intérprete, en Homero aún no está determinada la diferencia entre el logro técnico y el éxito mágico; de allí que el término téchne se aplique al saber hacer de los demiurgoí, categoría social que abarcaba indistintamente a los profesionales del metal y de la madera, las comunidades de adivinos, de heraldos, de curanderos y de aedos.

30 Para el uso ambiguo de la noción de theía moíra en el corpus platónico, cf. Stern-Gillet 2004, 195-199. Esta intérprete destaca que tal noción era infrecuente en la Grecia antigua y que Platón es uno de los autores que más la emplea, hasta el punto de que termina por reemplazar la noción de theía moíra por la de mímesis en su explicación del proceso poético.

31 Respecto de la relación entre esta imagen de los anillos magnetizados y el interés científico de Demócrito por el magnestismo, cf. Delatte 1934, 57. A la mayor parte de los intérpretes, como Wilamowitz 1919, II 43; Gadamer 1934, 189-190; Guthrie 1975, 206; Murdoch 1977, 11; Nehamas 
1988, 294, nota. 1; y Leszl 2004, 197, que suscriben la opinión de una actitud platónica negativa hacia los poetas en Ion, en tanto que éstos no detentan conocimiento alguno, les cuesta sobremanera armonizar esa actitud con pasajes tales como este de la metáfora del imán o anillos por los que pasa la influencia divina, en los que Platón brinda una bella y compleja descripción del estado mental del poeta. Por ello Guthrie 1975, 93, 206, por ejemplo, debe reconocer que en ciertos pasajes del Ion encontramos en Platón 'una cierta nota de simpatía' dirigida hacia los poetas, la cual contrasta claramente con el seco rechazo por su ignorancia divina formulado en la Apología. Este intérprete explica asimismo esa nota como parte de la ambivalencia de Platón en relación con la poesía, cuya actitud oscila entre la alabanza irónica (en Apología y Menón), cierta simpatía (Ion), una extraña mezcla de desaprobación y afecto (República y Leyes) y la estimación y admiración (Fedro).

32 Sobre la apelación del poeta a las Musas, cabe subrayar un contraste entre la concepción que puede observarse en Homero, Hesíodo y Píndaro, por un lado, y la teoría platónica de la posesión divina, por otro. Para la primera, el poeta apelaba a las Musas únicamente como autoridad superior, recibiendo de ellas ayuda divina en su relato, sin que ello implicase que aquéllas entraran en él o que le inspirasen o le poseyeran. En esta concepción homérico-hesiódica, lejos de estar fuera de sus cabales, el poeta era un maestro inteligente y un educador (o un primitivo sophistés), con una sabiduría y un saber propio. Para Platón, por el contrario, la Musa está, como destacan algunos intérpretes (véase, entre otros, Dodds 1951, 87, 101-102, nota 122; Tigerstedt 1970, 169, nota 32; y Guthrie 1975, 203-205, realmente dentro del poeta. De hecho, el concepto de inspiración poética como un género de enthousiasmós o manía extática contrapuesto al arte o la téchne no aparece antes de Platón (cf. Murray 1981, 87-89, 99-100), aun cuando ciertos especialistas (como Havelock, entre otros) persistan en igualar las nociones griegas arcaicas de inspiración con el concepto platónico de furor poeticus.

33 En este sentido Wilamowitz 1919, II 43, Jowett 1953, I 102, y Friedländer 1964, II 136 sostienen que en el Ion la vieja disputa entre filosofía y poesía -explicitada más tarde en República X- ya está operando en la mente de Platón. Más recientemente, Stern-Gillet 2004, 199, concibe el Ion no como un elogio, sino más bien como un temprano ataque a la poesía que preanuncia el de República. Para una lectura contraria y más afín a la nuestra, cf. especialmente Grube 1973, 278-279.

34 Sobre la 'opinión verdadera' o 'recta' (orthè dóxa) como algo 'intermedio' entre el conocimiento y la ignorancia, cf., entre otros, Symp. 202a2-9: ‘ ¿No sabes que el opinar rectamente, incluso sin poder dar razón de ello, no es ni saber, pues una cosa de la que no se puede dar razón no podría ser conocimiento, ni tampoco ignorancia, pues lo que posee realidad no puede ser ignorancia? La recta opinión es, pues, algo así como una cosa intermedia entre el conocimiento y la ignorancia'.

35 Greene 1918, 24, subraya al respecto que no cabe hablar en Menón de una 'depreciación de las obras de los poetas'.

36 Sobre la distinción entre las figuras del poeta y del filósofo en los diálogos tempranos (Apología, Ion y Menón) y medios (República), cf. especialmente Nussbaum 1986, 297-300, para quien el estado de delirio o de inspiración irracional del poeta se contrapone al buen sentido y autodominio del filósofo.

37 Véase en la misma línea Leg. V 727c4-d5. Otra mención de los 'buenos y antiguos legisladores' puede leerse en Charm. 154e8-155a3, 157d9-158a2; Hipp. mai. 285e36, Lach. 188a6-b4, Prot. 326d6, 343a1-b3; Symp. 209c7-e3, Rep. X 599c6-e4, Phaidr. 258b10-c5, Tim. 20d7-21d3, y Criti. 108c5-d8. Para el punto de vista positivo respecto de la poesía en Banquete, cf., entre otros, Else 1986, 12; Corrigan - Glazov-Corrigan 2004, 216-220.

38 Es interesante resaltar la frecuencia con la que Platón repite este sintagma en los diálogos tomados como antecedentes del Fedro.

39 Sobre la revalorización de estos poetas y legisladores, cf. especialmente Greene 1918, 19-20, y Asmis 1992, 344-345. 40 Para un análisis del sintagma 'de repente' (exaíphnes), cf. Rosen 1968, 288-325, Robin 1933, 183, y Nussbaum 1986, 249-252.

41 Guthrie 1975, 374-375, interpreta en este sentido que las 'imágenes de virtud' sólo pueden ser engendradas en el marco de los misterios menores.

42 Para una crítica del clímax de plenitud o del amor contemplativo y autosuficiente que supone la aprehensión de la Idea de Belleza, cf. especialmente Vlastos 1973, 3-42. En su análisis de la revelación final a la que se enfrenta el iniciado, Nussbaum 1986, 48, 249-252, sostiene asimismo que Platón termina por reconocer en Banquete que el logro de tal autosuficiencia racional exige el abandono de gran parte de la vida humana y de su belleza.

43 Para un análisis de las diferencias entre los planteos de República y Fedro respecto de la relación entre filosofía y poesía, así como de la poesía filosófica que asume el estilo socrático en este último diálogo, cf. WilamowitzMoellendorff 1919, 43, quien ya resaltaba cómo a la altura del Fedro Platón termina por reconocer el bien que existe en la creación inconsciente de los poetas; y Nussbaum 1986, 270, 486, según la cual no cabe, como interpretamos nosotros, hablar en Fedro de una plena rehabilitación o concepción positiva de la poesía tradicional que había sido desacreditada en República.

44 Basándose en el principio -clave para la consecución de su programa de reforma filosófico-política de la pólis ideal- de la especialización de las funciones, vimos que en Rep. III 395a1-b6 Platón le hacía sostener a Sócrates justamente la tesis contraria a la vertida aquí respecto del verdadero artista, es decir, la prescripción de la imposibilidad de la práctica simultánea de funciones (ya se trate de la práctica de los géneros trágico y cómico, o de rapsoda $\mathrm{y}$ actor a la vez, entre otras funciones). Sobre la aparente contradicción entre tales pasajes de Banquete y República, cf. Murdoch 1977, 148, y Guthrie 1975, 366, n. 139. 45 Entre los tópicos trágicos que vertebran el discurso de Aristófanes en el Banquete, caber destacar, entre otros: 
el recurso a la mitología vinculado al mito acerca de la integridad de nuestra antigua naturaleza humana y de su ulterior pérdida (Symp. 189d5-7); la hýbris de la antigua naturaleza humana (Symp. 190b5-c1); los seres humanos como juguetes de los dioses (Symp. 190c7-d6); la concepción trágica del éros como un intento de restauración de la antigua integridad perdida (Symp. 191c8-193c7); la no intervención de la razón práctica en el proceso de búsqueda erótica (Symp. 192b5-c2, 192c7-d2); la piedad e impiedad para con los dioses (Symp. 193a3-b2, 193d1-d5). Y entre sus tópicos cómicos, pueden mencionarse: los movimientos físicos de la antigua naturaleza humana (Symp. 190a4-d6); las deliberaciones de los dioses (Symp. 190c1-3); y la vinculación entre los pederastas y la política (Symp. 192a2-7). Sobre esta cuestión, véase especialmente Bury 1932, xxx, Jaeger 1957, 575-576, Lesky 1957-8, 254, 285, Dover 1966, 41-46, Nussbaum 1986, 238-243 y Nichols 2004, 203.

46 Sobre Sócrates (y, por tanto, Platón) como encarnación de este poeta tragicómico, cf., entre otros, HartlandSwan 1951, 3-18, 99-141, Rodríguez Adrados 1969, 1-28, Clay 1975, 238-261, Patterson 1982, 76-93, Stokes 1993, 128, Nightingale 1995, 1-12, y Riegel 2013, 277-282. Por su parte, Nussbaum 1986, 262-263, agrega que también puede considerarse como trágicómico el discurso de Alcibíades.

47 Para la analogía que la cosmética guarda con la retórica, la poesía mimética y la pintura, véase Belfiore 1983, 47, nota 10; Rodrigo 2001, 146-152, nota 27.

48 En Teeteto 176b1 llega a definir la vida filosófica como una 'imitación de la divinidad'.

49 El modelo dialógico-filosófico -y ello aparece claramente explicitado en Leyes VII 817a2-e3- constituye el mejor ejemplo de mímesis de la vida más bella y mejor, es decir 'una cierta poesía' filosófica que Platón erige finalmente como parádeigma para los futuras generaciones de poetas y maestros de niños y jóvenes

50 Sobre Platón como un pintor del éthos, cf. especialmente Villela-Petit 1991, 89-90.Le commerce de la vérité 